\title{
Stomata cells studies of Paraphalaenopsis spp. from in vitro and greenhouse condition
}

\author{
R. VITRI GARVITA ${ }^{*}$, HARY WAWANGNINGRUM ${ }^{\text {v }}$ \\ Research Center for Plant Conservation and Botanic Gardens, Indonesian Institute of Sciences. Jl. Ir. H. Juanda No. 13, Bogor 16123, West Java, \\ Indonesia. Tel./fax.: +62-251-8322187, `email: vitrigarvita@gmail.com; •"email: wawangningrum@gmail.com
}

Manuscript received: 25 October 2019. Revision accepted: 19 February 2020.

\begin{abstract}
Garvita RV, Wawangningrum H. 2020. Stomata cells studies of Paraphalaenopsis spp. from in vitro and greenhouse condition. Biodiversitas 21: 1116-1121. In vitro micropropagation is an efficient biotechnological strategy for conservation and commercial plantlet production. The ultimate success of in vitro micropropagation depends on the ability to transfer plants out of culture, known as acclimatization stage. The morphology, anatomy, and physiology of plantlets in in vitro culture conditions is different from the plants in environment condition (greenhouse), therefore they are unable to compete with soil microbes and to cope with the environmental conditions. The aim of this research was to determine stomata morphology and distribution of Paraphalaenopsis spp (Orchidaceae) from in vitro growth and greenhouse conditions. The leaf stomata cells of Paraphalaenopsis spp. (Paraphalaenopsis serpentilingua, Paraphalaenopsis labukensis, and Paraphalaenopsis Laycockii) was undertaken by observing the stomata preparation of the upper leaf and lower leaf by using microscope fitted with optic visual seven. The descriptive method was used to describe the stomata morphology by observing the epidermis of longitudinal section and stomata length of upper and lower leaf by using a microscope. The results showed that these plants had anomocytic type of stomata cells. The distributions of stomata are in the upper and lower epidermis leaf in all Paraphalaenopsis spp from in vitro growth and greenhouse.
\end{abstract}

Keywords: Greenhouse, in vitro, Orchidaceae, Paraphalaenopsis, stomata

\section{INTRODUCTION}

Micropropagation has been used for rapid production of high quality and disease-free of many plant species. The final phase of micropropagation is acclimatization. Once plantlets are well rooted, they must be acclimatized to greenhouse environment (ex vitro condition). The phase whereby plantlets are transferred from in vitro to ex vitro (greenhouse) environment is extremely important. The significance of environmental differences made a successful transfer from in vitro to ex vitro (greenhouse) conditions is difficult. There are numerous studies on in vitro propagation of orchids that have been published (Arditti 1996; Pospisilova et al. 1999; Jawan et al. 2010; Lesar et al. 2012; Lando et al. 2016).

Orchid lives in all continents except Antarctica. Orchidaceae is one of the largest flowering plant families in the world, ranging from small, ephemeral, terrestrial, perennial, epiphytic and succulents. Paraphalaenopsis spp. is a rare native orchid, epiphytic herb, and pendent, known as the "rat-tailed phalaenopsis" orchid with the longest leaf in the word. Paraphalaenopsis belongs to the subfamily Epidendroideae, a tribe of Vandeae, a sub-tribe of Aeridenae, of the family Orchidaceae. This genus consists of four species i.e. $P$. denevei, $P$. serpentilingua, $P$. laycockii and P. labukensis. Paraphalaenopsis has related to Phalaenopsis, Doritis, Aerides, Renanthera, and Kingidium. These orchids with a monopodial growth, epiphytes, endemic to Borneo (Kalimantan, Sarawak, and Sabah) and require warm temperatures, good air circulation, and high humidity. The habitats are partially shady, they should not be exposed to cold and likewise do not do well in extreme heat. The roots are cylindrical, whitish-green, thick and branching. The stems are very short or not clearly visible, unbranched and leafy. The leaves are terete or almost terete with point in all directions and hang naturally like a pencil or tail rats, up to $1 \mathrm{~m}$ in length, dark green, coarse-textured, fleshy and fluffy with a number of 3-7 strands are arranged alternately with dense spacing. Inflorescence appears from a stem node with more than one flower. The flower is resupinate, with spreading perianth, and blooms grow from the base move forward, usually carry a strong scent similar to cinnamon or ripe bananas, depending on the species. The Sepals are oblanceolate to elliptic, free and spreading with oblique of laterals; the petals are oblanceolate and spreading. The labellum is firmly attached to a column foot, clawed at base, trilobed and lacking a spur. The column is tereteclavate, anther-cap obovoid with two pollinia and stigma in a ventral cavity. The ovary has a six-ridged and rarely angular. The flowers normally stay on the plant about 2 to 3 weeks, but do not last long when cut (Orchid Society of South East Asia 1994; Chan et al. 1994; Yam 1994; Wood 2003; Handoyo 2010; Pridgeon et al. 2014).

Paraphalaenopsis serpentilingua was described by J.J. Smith in 1993. The unique flowers with the shape of the mid lobe of the lip, which resembles the snake tongues, have the smallest flowers in this genus ( 3 to $4 \mathrm{~cm}$ across). The flowers are scented. The sepals and petals are white; the lip is lemon yellow with mauve bars, transversely 
striated with purple. The flower spike is the longest of this genus are well spaced along 30 to $35 \mathrm{~cm}$. Distribution in Borneo is Kalimantan Barat (Singkawang area, Kapuas River, Sanggau area, and Sintang area). Paraphalaenopsis laycockii was described by M.R. Henderson in 1935. It was named after John Laycock, a pioneer of orchid hybridization in Singapore. The flowers are the showiest, 7 to 8 across, and the inflorescence very short with a congested rachis, rarely up to $15 \mathrm{~cm}$ long with more than 10 flowers. The sepals and petals are pure-white or pale pink, sometimes pinkish lilac. The center of the lip is yellow with pinkish stripes and the lobe ends are pink. Distribution in Borneo is Kalimantan Timur. Paraphalaenopsis labukensis was described by P. S. Shim, A. Lamb and C.L. Chan in 1981. The inflorescence is slightly erect to pendulous, around $15-20 \mathrm{~cm}$ with more than 15 flowers. The flowers are 6 to $9 \mathrm{~cm}$ across, the sepals and petals are solid chestnut brown on a yellowgreen background. The lip is white with purple stripes. Distribution in Borneo is Sabah (Kuala Labuk, Mt. Kinabalu) (Chan et al. 1994; Orchid Society of South East Asia 1994; Yam 1994) (Figure 1). The population of these orchids in the wild has begun to decrease. Major threat of these orchids is over-collecting for the nursery trade. Therefore, tissue culture technique is one of methods to improve the existing cultivars and to have a large scale of plants in a comparatively short time compared to conventional breeding.

The best growth of Paraphalaenopsis is in a place with shade or light shade, this condition related to leaf morphology characters such as stomata. Stomata, the small pores on the surfaces of leaves are found in the epidermis and cuticle layer of leaves, which regulate the flow of gases and water in and out of leaves and therefore plants as an entire. Stomata are bound by a pair of guard cells that control the exchange of gases and water between the interior of the leaf and the atmosphere, which can activate stomata closer if they sense water stress. There are three classifications of subsidiary cell formations: anisocytic, paracytic or diacytic. Each of these three classifications does essentially supporting guard cells and protecting epidermal cells against guard cell expansion. Subsidiary cell is composed of the same cellular material, but have different from the composition of the guard cells and the other epidermal leaf cells. Anisocytic cells are unequal in appearance to each other, these may be composed of three or more cells, which surround the guard cells, buffering it from the other epidermal leaf cells. Paracytic cells are arranged about the long axes of the stomata cells. Diacytic cells are arranged at right angles to the stomata cells (Ferry 2008).

Mostly, a reflex of the environmental condition in which plant has developed and the result of a complex process that reveals the phenotypical plasticity are in anatomical characteristics. The physiological and anatomical characteristics of micropropagated plantlets in response to the in vitro environment are different from field-grown plants (greenhouse conditions). Plantlets are lack of surface wax on the leaf which can be caused in high water loss and also has a great susceptibility to leaf scorch from sun and crop protection chemicals (Ehirim et al. 2014). The stomata of leaves in some plants cultivated in vitro may also atypical and incapable of complete closure under low relativity humidity such as in in vitro conditions. Leaf structure also can illustrate the plant response to environmental stresses, such as a low supply of soil nutrients. In majority of orchids, the stomata are mostly flushed with the epidermis (Mulgaonkar 2005).

The information about epidermis cells and stomata cells of Orchidaceae are limited. This is why this research was conducted to give more information about epidermis cells and stomata cells of Orchidaceae, such as Paraphalaenopsis spp. This research aimed to know the differentiation of stomata Paraphalaenopsis spp. from upper and lower surfaces of leaves on the in vitro growth and on the greenhouse.

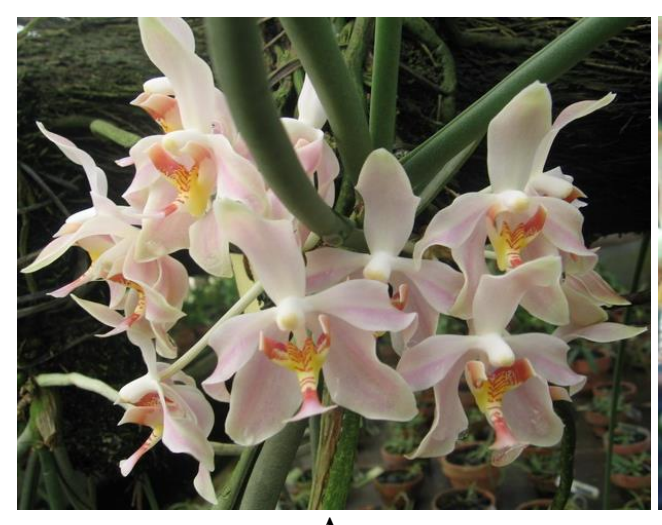

A

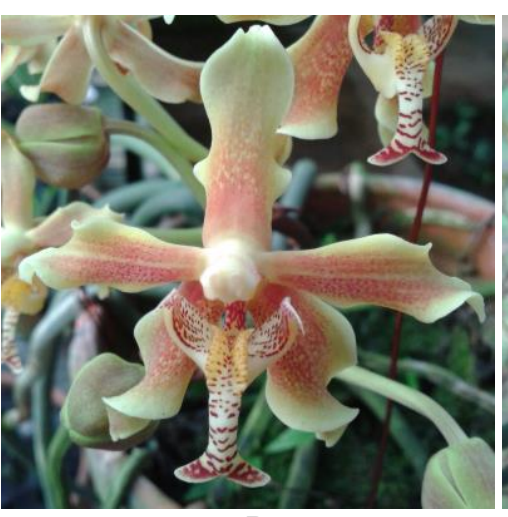

$\mathbf{B}$

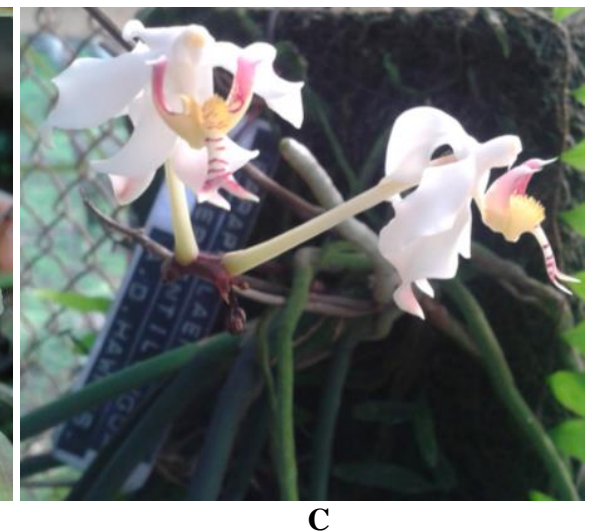

C

Figure 1. Flower of Paraphalaenopsis spp.: A. P. laycockii, B. P. labukensis, C. P. serpentilingua 
Table 1. Mean of epidermis and stomata length of Paraphalaenopsis spp. from in vitro and greenhouse

\begin{tabular}{llcc}
\hline Location & Paraphalaenopsis & Upper leaf $(\boldsymbol{\mu m})$ & Lower leaf $(\boldsymbol{\mu m})$ \\
\hline In vitro & P. labukensis (epidermis) & $45.226 \pm 5.203$ & $47.299 \pm 6.410$ \\
& P. laycockii (epidermis) & $49.525 \pm 7.324$ & $45.618 \pm 6.489$ \\
& P. serpentilingua (epidermis) & $45.861 \pm 9.374$ & $46.195 \pm 5.631$ \\
& P. labukensis (stomata length) & $53.943 \pm 5.716$ & $55.862 \pm 6.429$ \\
& P. laycockii (stomata length) & $56.057 \pm 3.309$ & $53.456 \pm 3.484$ \\
& P. serpentilingua (stomata length) & $48.301 \pm 6.717$ & $50.791 \pm 5.802$ \\
Greenhouse & & $54.900 \pm 8.439$ & $50.574 \pm 7.197$ \\
& P. labukensis (epidermis) & $54.908 \pm 6.952$ & $50.010 \pm 4.414$ \\
& P. serpentilingua (epidermis) & $66.939 \pm 10.067$ & $66.795 \pm 8.157$ \\
& P. labukensis (stomata length) & $68.949 \pm 4.666$ & $69.425 \pm 4.420$ \\
\hline
\end{tabular}

\section{MATERIALS AND METHODS}

Plantles of Paraphalaenopsis serpentilingua, Paraphalaenopsis laycockii and Paraphalaenopsis labukensis grown on half of Murashige and Skoog medium with addition of banana extracts were used for the experiments (Figure 2). Cultures were incubated at $25-28^{\circ} \mathrm{C}$ at a photoperiod of $12 \mathrm{~h} /$ day with illumination by $40 \mathrm{~W}$ cool white inflourescent lights. Also were used plants of Paraphalaenopsis serpentilingua, Paraphalaenopsis laycockii and Paraphalaenopsis labukensis grown on greenhouse conditions (Figure 3). The plant materials were grown at Research Center for Plant Conservation and Botanic Gardens, LIPI, Bogor, Indonesia.

In this study, preparation for upper (adaxial) and lower (abaxial) mature leaves peelings were taken to study stomata characteristics of Paraphalaenopsis spp. The leaf anatomical of orchids (stomata) was observed using microscope fitted with optic visual seven. Slides were viewed under $100 \mathrm{x}$ magnifications. Both surfaces of leaves were coated with clear nail varnish about 5-10 minutes, and then put the scotch tape over the nail polish. Pull it up and place it to object-glass. Photomicrographs were taken from good preparation using microscope fitted with optic visual seven. The length of stomata and epidermal cells has measured on both surfaces.

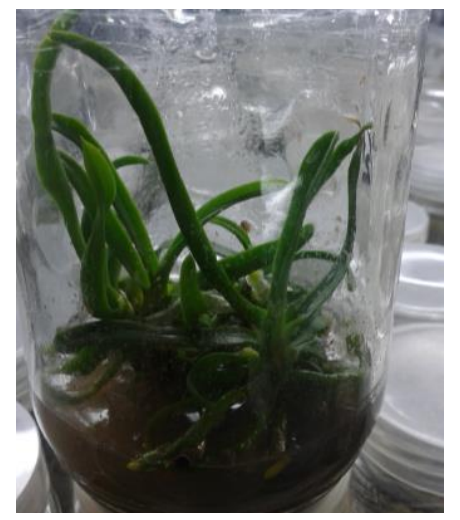

Figure 2. Micropropagation of Paraphalaenopsis spp.

\section{RESULTS AND DISCUSSION}

The epidermal cell shapes of Paraphalaenopsis spp. are irregular and we can tell that the distributions of the stomata of Paraphalaenopsis spp. are amphistomatic (Figure 4). It means that stomata occur either on both surfaces. Stomata types of Paraphalaenopsis spp. are anomocytic, based on Sreelakshmi et al. (2014) stoma lacks morphologically differentiated subsidiary cells in both upper and lower surfaces and surrounded by irregular epidermal cells.

The stomata characteristics and epidermal cells of Paraphalaenopsis spp. from in vitro and from greenhouse are shown in Figure 5. Stomata can be found between epidermis cells, in upper and lower epidermis of the leaf in all species. The results for upper leaf and lower leaf of Paraphalaenopsis spp. showed that epidermis length and stomata length at greenhouse conditions higher than in vitro conditions (Table 1). This study gave a different result on size stomata of P. laycockii (M.R. Henderson) A.D. Hawkes with a previous study by Yulia and Juliarni (2007). The previous study has a larger stoma measuring $(66.8 \mathrm{x}$ $57.3 \mu \mathrm{m}$ ), our study gave $56.057 \pm 3.309 \mu \mathrm{m}$ on upper leaf and $53.456 \pm 3.484 \mu \mathrm{m}$ on lower leaf. This difference can be caused by our study used $P$. laycockii from in vitro condition.
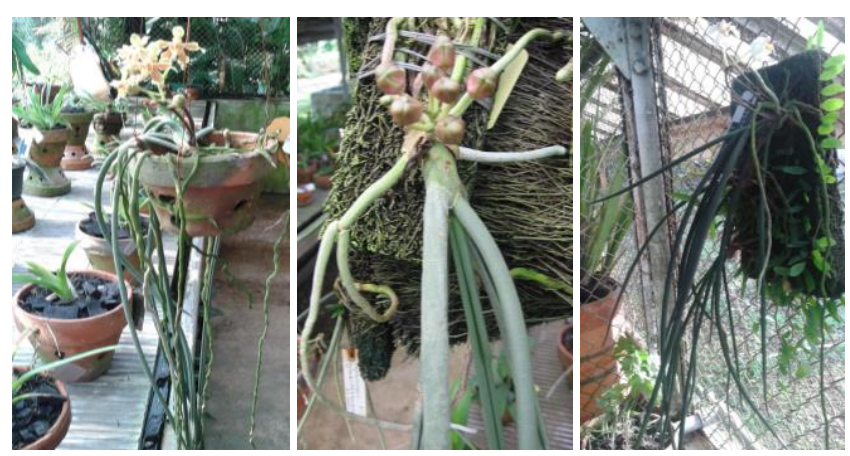

Figure 3. Paraphalaenopsis. A. P. labukensis, B. P. laycockii, C. $P$. serpentilingua 


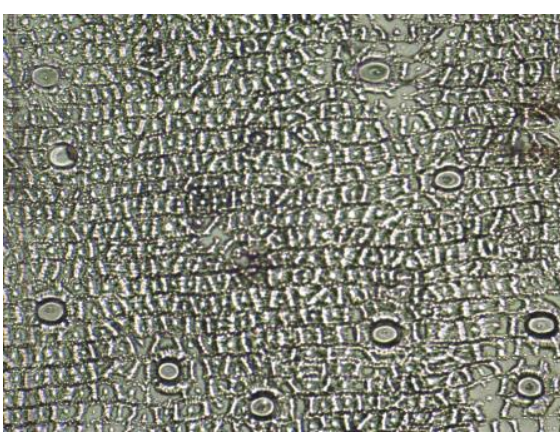

A

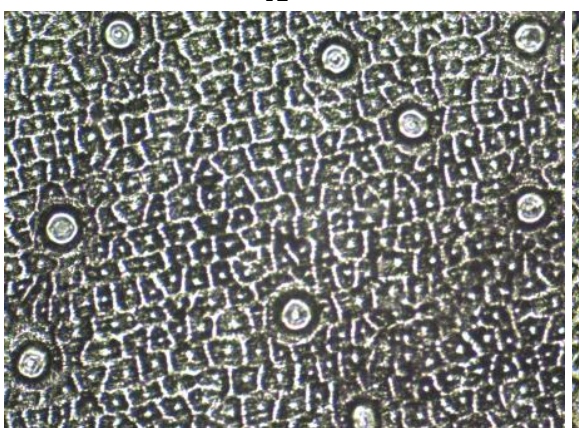

D

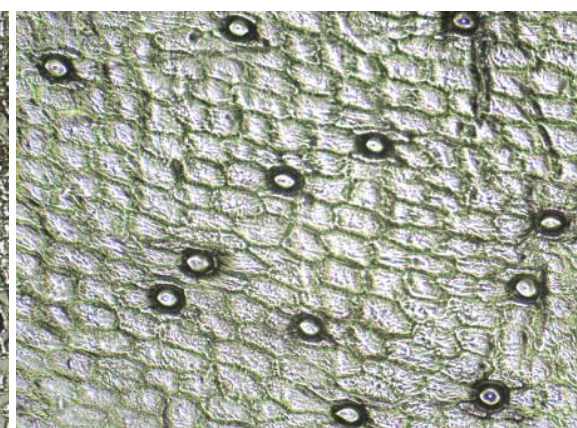

B

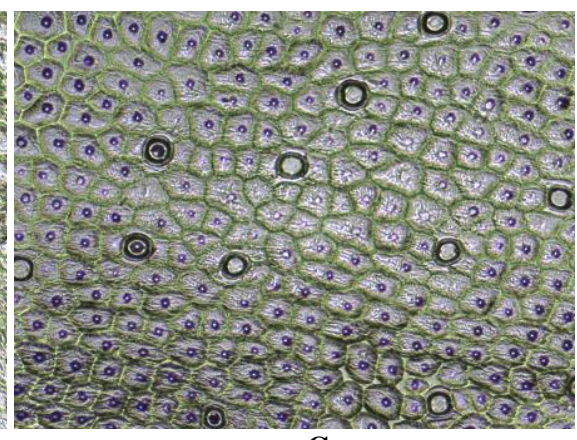

C

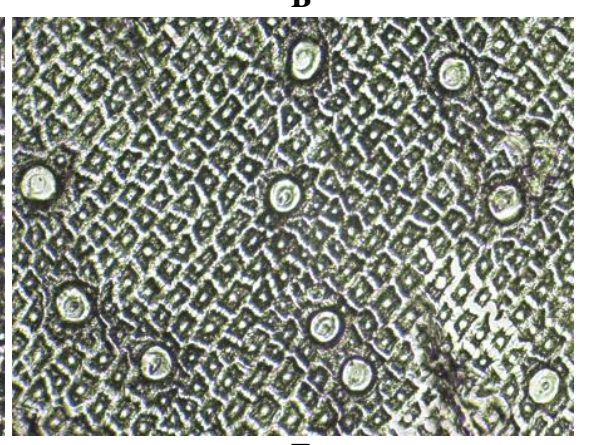

$\mathbf{E}$

Figure 4. Leaf stomata from in vitro propagation of: A. P. labukensis, B. P. laycockii, C. P. serpentilingua; Leaf stomata from Greenhouse propagation of: D. P. labukensis, E. P. Serpentilingua. Optical magnification of 10x10

Based on Arditti (1992), there are two categories of orchid leaves: (i) Thin, such as those of Cymbidium, Cypripedium, Dendrobium, Calanthe, Phaius, and Paphiopedilum; (ii) Thick and fleshy, as in Cattleya, Rhynchostylis, Dendrobium, terete Vanda and several Oncidium. Thicker leaves have larger cells and more cell layers in their mesophylls; the cuticles on upper and lower epidermis of such leaves are thicker but the number of stomata is smaller. The leaves of Paraphalaenopsis are thick and fleshy, as seen in Figure 3.

Morphological adaptations of epiphytic orchids such as thick, fleshy leaves and pseudobulbs are used to store water and reduce drying. There are other adaptations such as succulence and the ability to fix carbon with Crassulacean acid metabolism, this is similar to succulent family Crassulaceae. The terete-leaved orchids, Paraphalaenopsis, do not possess pseudobulbs or fleshy stems but do possess succulent, drought-resistant leaves. The foundation of leaf physiological functions and consequentially is the anatomical structure of the leaf, if there are changes in leaf anatomical structure it will greatly affect plant growth and metabolism (Pandey et al. 2009).

The tiny pores in orchid species to share this trait in leaf surfaces, stomata that open during the day to take advantage where atmospheric humidity is the highest, or keep it closed if dry conditions occur (Dressler in Predovich 2012). The stomata are interspersed in the parenchymatous groundmass of leaves (most abundant in the lower epidermis) and associated with subsidiary cells. A stoma consists of the stomatal aperture and two enclose guard cells. The production of leaves in in vitro plantlets with low light intensities is the same with the resemble shade or hydrophytic leaves ex vitro. These conditions make leaves often have little epicuticular and cuticular wax formation and malfunctioning stomata. Stomata, as regulators of gaseous and water exchange, have developed a specific structure and unique physiology, both functionally coordinated to result in movement of guard cells. When stomatal aperture open, it allows $\mathrm{CO}_{2}$ to enter the leaf and results in water loss through transpiration (Ortega-Loeza et al. 2011; Beck 2012). Predovich (2012) compares stomata density of the epiphytic Pleurothallis aristata and Maxillaria sp. (Orchidaceae) under experimental conditions of dry and humid conditions. Maxillaria sp. has higher stomata density because has a pseudobulb and has a larger leaf surface area.

The plantlet from in vitro have a special growing condition, heterotrophic metabolisms, such as diminished gas exchange, high air humidity, low irradiance, and use of sugar as carbon and energy source, which could cause inhibition of photosynthesis, abnormal stomata structure, and generally could lead high plantlet mortality during acclimatization. In vitro leaves may not develop a waxy cuticle and functional stomata to the same extent as found in greenhouse leaves (Pospisilova et al. 1999; Lesar et al. 2012; Lando et al. 2016). The stomata rhythms, morphology, and distribution based on the pathways of carbon fixation and light requirements for deacidification. 


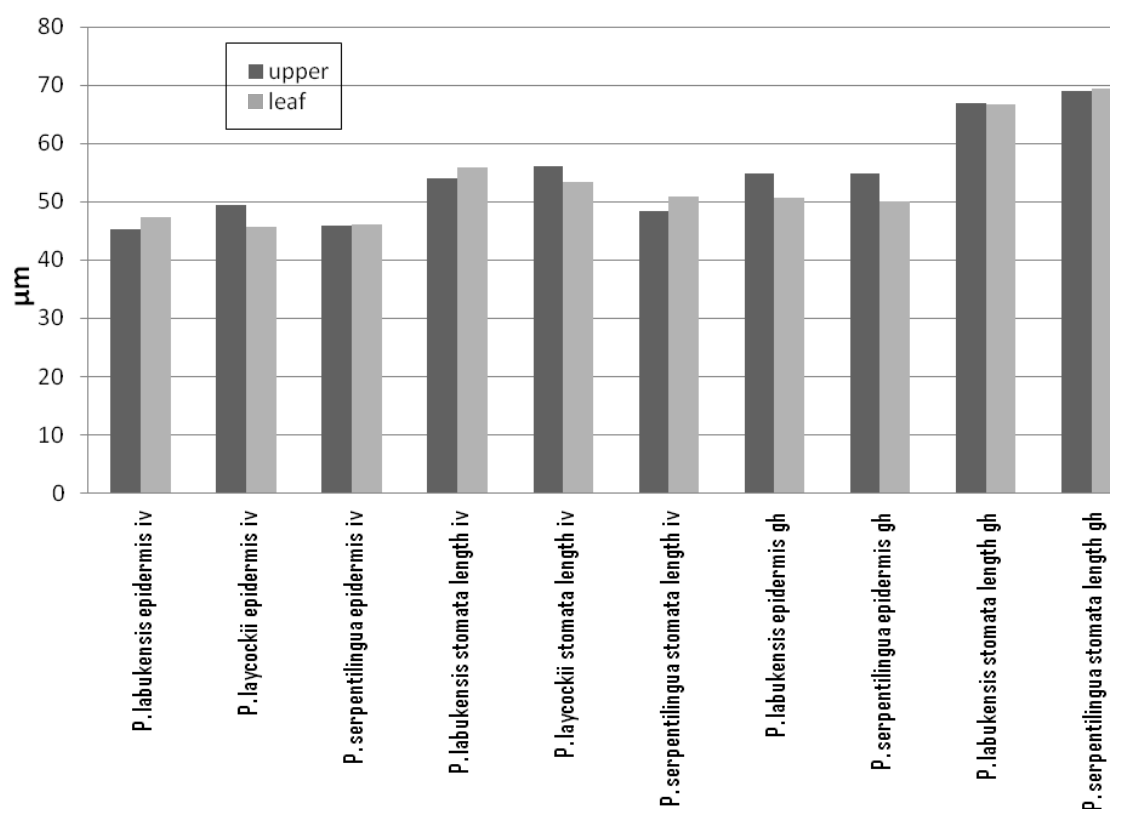

Figure 5. Mean of epidermis and stomata length of Paraphalaenopsis spp. from in vitro culture (iv) and greenhouse (gh)

Buyun (2013) analyzed the leaf surface micromorphology of Cattleya gaskelliana from in vitro to glasshouse condition by scanning electron microscopy (SEM); the leaves are hypostomatic and stomata are tetracytic type. The following changes of leaf surfaces from in vitro condition to ex vitro conditions have been observed: (i) configuration of epidermal cells changed; (ii) dimensions of typical epidermal cells reduced; 3) stomata density and their dimensions increased. Those changes, probably, can be regarded as an adaptation to avoid excessive rate leaf transpiration during a period of glasshouse conditions.

Roots supplied water and minerals through the leaf and stomata will open to take in carbon dioxide from the air, while providing for produces the sugars that are transported by vascular systems which feeds all the other plant parts. The frequency and position of stomata are organs and species that have specific characters, but also affected by environmental factors. The stomata in the lower epidermis, also known "hypostomatous, and the stomata in the upper epidermis, also known as epistomatous. The purpose of stomata is to control gas exchange between the plant and its surroundings. Stomata control of water loss allows plants to occupy habitats with fluctuating environmental conditions. The stomata are open, during periods of photosynthesis when carbon dioxide is utilized and the concentration in guard cell turgor is low, but during periods of very low light intensity when the carbon dioxide concentration is high, the stomata will close (Beck 2012). A number of environmental factors, including light, carbon dioxide concentration, humidity, wind, mineral nutrition, and temperature influences the changes in guard cell turgor which are opening and closing stomata.
There are four most common types pattern of guards cells and subsidiary cells: referred to as anomocytic (irregular), also called "ranunculaceous" (because this type is commontly occurrence in the Ranunculaceous); paracytic (parallel), also "rubiaceous"; anisocytic (unequal), also "cruciferous"; and diacytic (cross-celled), also "caryophyllaceous". The anomocytic type the guard cells and subsidiary cells have no well-defined pattern and there may be no subsidiary cells. The paracytic type is characterized by subsidiary cells and guard cells having parallel long axes. The anisocytic type is distinctive in have three subsidiary cells each of a different size. In the diacytic type, there are two subsidiary cells that have contiguous walls that are right angles to the long axis of the guard cells, and which enclose the guard cells (Figure 6.) (Beck 2012).

The stomata of Arachnis cv. Maggie Oei, Aranda cv. Deborah, Arundina graminifolia, Bromheadia finlaysoniana, Cattleya bowringiana X C. Forbesii and Spathoglottis plicata (Orchidaceae), based on Goh et al. (1977), occur only on the lower epidermis of the leaves and are located within hyperstomatic chambers formed by cuticular ledges extending from guard cells. Stomata of Dendrobium transparens Wall. ex. Lindl; Vanda tessallata (Roxb) and Cottonia peduncularis (Lindl.) are paracytic; and shaped of guard cells are kidney (Mulgaonkar 2005). The type of stomata of Grammatophyllum scriptum is mostly tetracytic, there are four epidermal cells surrounding by two guard cells (Pitoyo et al. 2015). Mulgaonkar (2005) was studied on dermal anatomy of two interesting corticolous orchids from Western Ghats, Cymbidium aloifolium Swart and Luisia birchea (A. Rich), showed that stomata are paracytic type, the stomatal frequency has been ranging between $21.62-37.3 / \mathrm{mm}^{2}$. 
Angela et al. (2015) had studied in six epiphytic orchid species in five genera with different type of stomata. Paracytic stomata were found in Cleisostoma filiforme (Lindl.) Garay, Eria pannea Lindl, Papilionanthe teres (Roxb.) Schltr, Papilionanthe vandarum (Rchb.f.) Garay and Schoenorchis gemmata (Lindl.) J.J. Smith. The other type of stomata is actinocytic, which was found in Oberonia oklongensis Chowlu.

There were differences plants cultivated between in vitro and greenhouse. The in vitro plants have low irradiance, aseptic conditions, high humidity, and availability of sugars and nutrients from culture media to allow for heterotrophic growth. The protection mechanisms of in vitro plants are reduced like waxy cuticles, stomatal regulation, and leaf hairs, those morphological characteristics make them vulnerable to the field environments (greenhouse). The stomata are anomocytic type and can be found in upper and lower epidermis leaf of Paraphalaenopsis spp. The length of epidermis and stomata at greenhouse condition are longer than in vitro conditions.

\section{ACKNOWLEDGEMENTS}

The authors are thankful to Research Center for Plant Conservation and Botanic Gardens, Indonesian Institute of Sciences (LIPI), Bogor, Indonesia for providing the requisite funds and facilities to carry out the research.

\section{REFERENCES}

Angela N, Lu KC, Sharma BH, Rao NA, Vij SP. 2015. Anatomy of some terete-leaved orchid species. Kasetsart J Nat Sci 49: 13-21. http://kasetsartjournal.ku.ac.th/kuj_files/2015/A1506091553473593.p df

Arditti J. 1992. Fundamentals of orchid biology. John Wiley \& Sons Co. Inc, New York.

Arditti J. 1996. Orchid micropropagation: the path from laboratory to commercialization and an account of several unappreciated investigators. Bot J Linn Soc 122: 183-241

Beck CB. 2012. An introduction Plant Structure and Development: Plant anatomy for the twenty-first century. Second edition. Cambridge University Press, UK.

Buyun L. 2013. Adaptative changes of leaf surface of tropical orchid Cattleya gaskelliana (N.E.Br.) B.S. Williams after transferring from in vitro to ex vitro conditions. Mod Phytomorphol 3: 235-238. DOI: 10.5281/zenodo. 162037
Chan CL, Lamb A, Shim PS, Wood JJ. 1994. Orchid of Borneo (Vol.1) Introduction and a selection of species. The Sabah Society. Kota Kinabalu, Malaysia.

Ehirim BO, Ishaq MN, Aqboire S, Solomon C, Ejizu AN, Diarra A. 2014. Acclimatization: an important stage in tissue culture. Asian Am Plant Sci Res J 1 (1): 1-7. http://www.aarpub.com/Journals.php

Ferry RJ. 2008. Stomata, subsidiary cells, and implications. The McAllen Intl Orchid Soc J 9 (3): 9-16.

Goh CJ, Avadhani PN, Loh CS. 1977. Diurnal stomatal and acidity rhythms in orchid leaves. New Phytol 78 (2): 365-372. DOI 10.1111/j.1469-8137.1977.tb04840.x

Handoyo F. 2010. Orchids of Indonesia (Vol 1.) Indonesian Orchid Society. Indonesia. [Indonesian]

Jawan R, Gansau JA, Abdullah JO. 2010. In vitro culture of Borneo's endemic orchid, Vanda dearei. Asian Pac J Mol Biol Biotechnol 18 (1): 203-207.

Lando AP, Wolfart MR, Fermino PCP, Santos M. 2016. Structural effects on Cattleya xanthina leaves cultivated in vitro and acclimatized ex vitro. Biol Plant 60 (2): 219-225. DOI: 10.1007/s10535-016-0589-3

Lesar H, Hlebec B, Ceranic N, Kastelec D, Luthar Z. 2012. Acclimatization of terrestrial orchid Bletilla striata Rchb.f. (Orchidaceae) propagated under in vitro conditions. Acta Agric Slov 99 (1): 69-75.

Mulgaonkar MS. 2005. Dermal anatomy of two interesting corticolous orchids from the Western Ghats. Indian J Appl Pure Biol 20 (2): 305308.

Mulgaonkar MS. 2005. Studies on dermal anatomy of three corticolous orchids from India. Intl J Mendel 22 (3-4): 105-107.

Orchid Society of South East Asia. 1994. Orchid Growing in the Tropics. Times Editions Pte Ltd., Singapore.

Ortega-Loeza MM, Salgado-Garciglia R, Gomez-Alonso C, Avila-Diaz I. 2011. Acclimatization of the endangered mexican epiphytic orchid, Laelia speciosa (H.B.K) Schltr. Eur J Environ Sci 1 (2): 48-54.

Pandey SK, Singh H, Singh JS. 2009. Species and site effects on leaf traits of woody vegetation in a dry tropical environment. Curr Sci 96 (8): $1109-1114$.

Pitoyo A, Hani MR, Anggarwulan E. 2015. Application of chitosan spraying on acclimatization success of tiger orchid (Grammatophyllum scriptum) plantlets. Nusantara Biosci 7 (2): 185191. DOI: 10.13057/nusbiosci/n070222

Pospisilova J, Ticha I, Kadlecek P, Haisel D, Plzakova S. 1999. Acclimatization of micropropagated plants to ex vitro conditions. Biol Plant 42 (4): 481-497.

Predovich S. 2012. Stomata density of orchids and cloud forest humidity. Oregon Undergrad Res J 3 (1). http://journals.oregondigital.org/ouri/

Pridgeon, AM, Cribb PJ, Chase MW, Rasmussen FN. 2014. Genera Orchidacearum, Volume 6, Epidendroideae (Part 3). Oxford University Press, United Kingdom.

Sreelakshmi V, Sruthy EPM, Shereena J. 2014. Relationship between the leaf area and taxonomic importance of foliar stomata. Impact J 2 (7): 53-60.

Wood JJ. 2003. Orchids of Borneo, Vol 4. The Sabah Society. Kota Kinabalu, Malaysia.

Yam TW. 1994. Breeding with Paraphalaenopsis. Am Orchid Soc Bull 63 (12): 1358-1365.

Yulia ND, Juliarni. 2007. Paraphalaenopsis laycockii (M.R. Henderson) A.D. Hawkes: Tinjauan terhadap morfologi tanaman dan anatomi daun. Buletin Kebun Raya Indonesia 10 (2) : 47-52. [Indonesian] 